\title{
Representation of Islamic Values in Film Duka Sedalam Cinta
}

\author{
Hasnil Aflah, Rahmanita Ginting \\ Master of Communication \\ University of Muhammadiyah Sumatera Utara (UMSU) \\ Medan, Indonesia \\ rahmanita_ginting@umsu.ac.id
}

\begin{abstract}
Film is one of mass media, as well as radio, television, and newspapers, have moral responsibility to provide educational value, goodness value as well as religious values. This purpose of this study is to analyze representation of Islamic values in Film Duka Sedalam Cinta. This research used a descriptive qualitative research method. It considers meaning as the main attention. The form of religious values in question is the Islamic values conveyed through message that exist in the film. The analysis method used is semiotics according to Fiske with the analysis unit consists of three levels: reality level, representation level, ideology level. The finding indicates that the representations encapsulate the perception of Islamic value in film Duka Sedalam Cinta may contribute towards establishing a more democratic and peaceful.
\end{abstract}

Keywords—representation; islamic value; film; semiotic fiske

\section{INTRODUCTION}

National films shine again with the emergence of young directors who have tremendous potentials such as Garin Nugroho, Riri Riza, Mira Lesmana, Rizal Mantovani, Rudi Sudjarwo, Hanung Bramantyo, etc. The emergence of these young filmmakers is in line with the emergence of films having the theme of Islam [1] and the number of works of Islamic literature that has been bestseller become a movie theater. It is interesting to be observed in the development of national film today. The national films having theme of Islam after the dissemination of the film Ayat-ayat Cinta received tremendous acclaim from the Muslim society, especially youth of Islam. Accordingly, the researchers wants to relate it to the research title that the researchers wrote as Representation of Islamic Values in Film Duka Sedalam Cinta.

In accordance with its function, the film is one form of mass media. In general, mass media have the informative, educative, and entertaining function for communicant. It means that every film produced certainly contains a message for the audience. Message from the movie Duka Sedalam Cinta aims to invite the society especially Muslims to always keep the values of Islam in daily life. The Islamic values expressed in this study are Islamic values expressed in dress dialogue and class by some of the actors limited by researcher between Gagah and Ustadz Ghufron. The goal is to facilitate researchers in analyzing the dress, dialogue and class on the movie "Duka Sedalam Cinta" with a duration of 1 hour 43 seconds 21 seconds. Islamic values taken by researchers are 3 levels of analysis John Fiske. "Duka Sedalam Cinta" is a film that lifts the theme of life containing elements of Islamic values that are good for society. Therefore, in this research the researchers uses John Fiske's semiotic analysis method, by analyzing the 3 levels of reality level (from 8 codes, the researchers limits only to the costume code), the level of representation (code selected only on dialogue code) and ideology level ( the code selected is the class code).

The research purpose of this study is to analyze the Islamic values at the level of reality (costume code), level of representation (dialogue code) and level of ideology (class code).

\section{LITERATURE REVIEW}

\section{A. Understanding Communication}

Communication comes from the Latin "communicatus" which means "sharing" or "belonging together". Means communication is the process by which individuals in relationship groups, organizations, and communities create and use information to relate to one another and with the environment [2]. Communication science is a science that conveys the statement between people, which aims to change the behavior, attitude, opinion, so that communicant can behave in accordance with the communicator (the existence of effect).

Besides discussing general communication, the researchers explain a bit about Islamic communication in this chapter, because the research about the film that researchers do is related to Islamic communication. Islamic communication is the communication of Muslims that Islamic communication is more focused on the system with a background of philosophy (theory) is different from the perspective of non-Islamic communication. With more clearly Islamic communication based on Al-Qur'an and As -Sunnah. By itself Islamic (Islamic) communication is tied to a special message, dakwah because Al-Qur'an and Hadith is a guide for the whole of nature and also is (contains) warning, warning and reward for man who believes and do virtue (Surat al-Ashr 1-5). 


\section{B. Representation}

Piliang explains, representation is basically something that is present but shows something beyond himself that he is trying to present [3]. Representation does not refer to itself but to the others. This means that the world is not merely reflected on us through the representational system, but we are actually constructing the meaning of matter in the world through representation. So that representation is more defined as a construct of meaning than just a reflection of reality.

\section{Movies}

Tan and Wright describe the film that the film is generally built with many signs [4]. The signs include various signaling systems that work together well in an effort to achieve the expected effect. Film is one mass communication media, is said to be mass communication media because it is a form of communication that uses channels (media) in communicating communicators and communicants in bulk, in the sense of large numbers, spread everywhere, heterogeneous and anonymous, and certain effects.

Film is one mass communication media, is said to be mass communication media because it is a form of communication that uses channels (media) in communicating communicators and communicants in mass, in the sense of a large number, scattered everywhere, heterogeneous and anonymous, and certain effects. Film and television have a resemblance, primarily its audiovisual nature, but in the process of delivering to audiences and production processes is slightly different. The film displays reality which is a fictitious reality, not a real reality or a plagiarism of that reality.

\section{Semiotics of John Fiske}

John Fiske argues that what is displayed on television or movie screens is a social reality in other words reality is a product produced by humans, so Fiske divides coding in three levels of encoding of television shows, which in this case also applies to movies and dramas namely

- The level of reality (dress code)

- Level of representation (dialogue code) and

- Ideology level (class code) [5]

This research aims to see the representation of Islamic values in the movie "Duka Sedalam Cinta". John Fiske argues that what is displayed on television or movie screens is a social reality in other words reality is a product produced by humans.

\section{E. Islamic Values}

Sumijati [6], the film as one of the mass media is a powerful medium for transforming and internalizing Islamic values. This is due to his ability to reach audiences. Islamic religious values that contain the rules of God which among others include rules that regulate the relationship of man with God, human relationships with humans, and human relationships with nature as a whole. According to Suroyo [7] that aspects of Islamic teachings in essence can be divided into 3 types, namely the Aqedah values, worship values, and moral values.

\section{RESEARCH METHODS}

According to Moloeng [8] that research intends to understand the phenomenon of what is experienced by research subjects such as behavior, perception, motivation, action, etc., holistically and by description way in the form of words and language, on a special context which is natural, and by utilizing various natural methods of behaviors and written or spoken words from observed persons. Semiotics John Fiske analysis is used in this study.

While this research type including the type of qualitative research with based on: data that appears in the form of words and not a series of numbers. In addition, with descriptive research method means to describe variable by variable, one by one.

The main data in this research is the dress, dialogue and class of film actors that have been limited by researchers between Gagah and Ustadz Ghufron, the rest is addition such as article documents and others.

According to Patton in [9] the researchers must always remember is how analysis is done, the researchers must monitor and report the analysis process and procedures as honestly and completely as possible.

\section{RESULTS AND DISCUSSION}

As we know that, the film is an audiovisual communication media to deliver a message to a group of people who gathered in a certain place. Any movie messages on mass communication can take any shape depending on the film's mission. However, generally a movie can include a variety of messages, be it educational messages, entertainment and information. The message in the movie is to use the symbol mechanisms that exist in the human mind in the form of message content, voice, speech, conversation and so on.

Based on the analysis of the researchers above, it can be seen that the code represents the Islamic values in the movie "Duka Sedalam Cinta" with the code taken is oral from the words (dress, dialog and class code) that occurs between Gagah and Ustadz Ghufron. In addition, this dress, dialogue and class must have significance in the film as representation of Islamic values.

An overview of Indonesian films that have a religious background in November 2017 is the "Duka Sedalam Cinta" movie, tells the story of Mas Gagah change from not study Islamic science, and being someone who loves studying Islam, and applying every the science he acquired during he stayed in South Halmahera. Discussion of Duka Sedalam Cinta movie was not just a film intended solely for entertainment, but the various meanings contained in this film. When examined more deeply, the film lifted from this literary work has so many good Islamic values for the community.

\section{A. Level reality, selected to dress}

At this first level, the author only takes one code to represent the Islamic values in the movie Duka Sedalam Cinta. The code is the costume code. Analysis on this costume, researchers only focus on Gagah and Ustadz Ghufron. From 
the costumes worn by Gagah and Ustadz Ghufron looks very reflect the typical costume of a Muslim. Islamic values in the use of movie costumes Duka Sedalam Cinta is seen from the turban and the clothes they use are Moslem / Muslim dress (koko shirt). And the researchers interpreted that the use of the clothing showed Gagah and Ustadz Ghufron was a Muslim who was very guarded or uphold the values of Islam in everyday life.

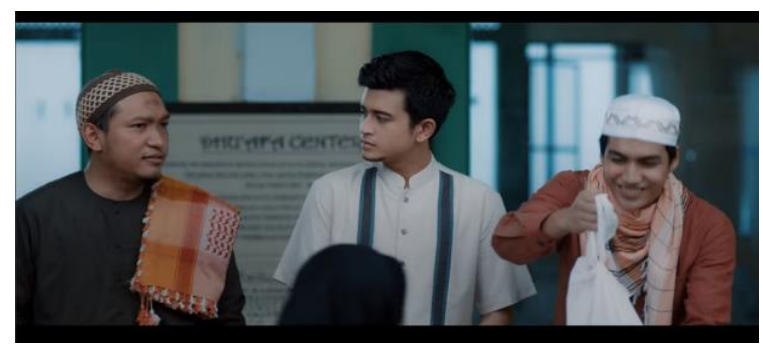

Fig. 1. The costumes worn by Gagah and Ustadz Ghufron are the common clothes worn by Muslim.

\section{B. Level Representation (selected to dialogue)}

Scene dialogue Gagah and Ustadz Ghufron at Dhuafa Center Ternate City, Halmahera. The atmosphere at that time giving infaq and alms to the dhuafa in ternate city, on the terrace Dhuafa Center.

Ustadz Ghufron: The public figures as well as those who are able to work together with the Regional Government to build this place for the dharma, anyone who is required is advised to take this place.

\section{Gagah: For what kiyai?? Why kiyai do this all ??}

Ustadz Ghufron: This does not state what we give and what we have. It's about what God has for us and what we can give to others. You will find this answer; you will understand why all this is here, gagah, life is too short when we can give something useful for the others. This principle of gratitude, there are we receive, there is what we give. Work hurt and gives hurt.

Dialog Gagah and Ustadz Ghufron above is a representation of Islamic values contained in the movie "Duka Sedalam Cinta". The dialogue discusses how the role of community leaders and people who have sufficient wealth willing to provide infaq and alms to the dhuafa. Because their right is in the wealth of the society of the capable and affluent so that the name giving to those who need the goal is only received a reply from Him, in accordance with the meaning of gratitude, what we receive, something we love. Islamic values that researchers associate in this film are aqidah values, religious values, and moral values. From the above discussion the value of aqidah embedded in the movie Duka Sedalam Cinta is how aqidah a true Muslim who was taught by the Prophet Salallahu 'Alaihiwasallam that is loving the dhuafa, the poor and orphans. A person's person can be seen from his aqidah against his religion, against his obedience to his Creator, Allah Subhanahu Wata'ala. If aqidah someone good then automatically also along with the worship that is done well, then morals also look polite and soothing if all done just except the reward of Allah Subhanahu Wata'ala.

\section{Level ideology (selected class code)}

At this level, researchers analyze the class code according to John Fiske with a focus on Gagah. Film Duka Sedalam Cinta tells the story of Gagah who is a handsome, rich, model and highly admired young woman. Gagah is a young man who looks from his daily life come from among young people who have a wealthy life. Looks are always cool and fashionable. Always use a car every trip anywhere and have a hobby photographer and also students in architectural techniques. Class code in this level of representation explains the background of a man named Gagah in the movie Duka Sedalam Cinta this is that before knowing Islam, Gagah's life spent more time with young people's life of fun, music, and fashion. After knowing Islam, Gagah's life that is very neglectful his afterlife finally chose to be more active in the very loving environment of God who has created Him, approaching a life full of Islamic values. The more glamorous Gagah life was stopped and Gagah spent much of his time in the mosque and shared with poor children living on the outskirts of the capital city of Jakarta.

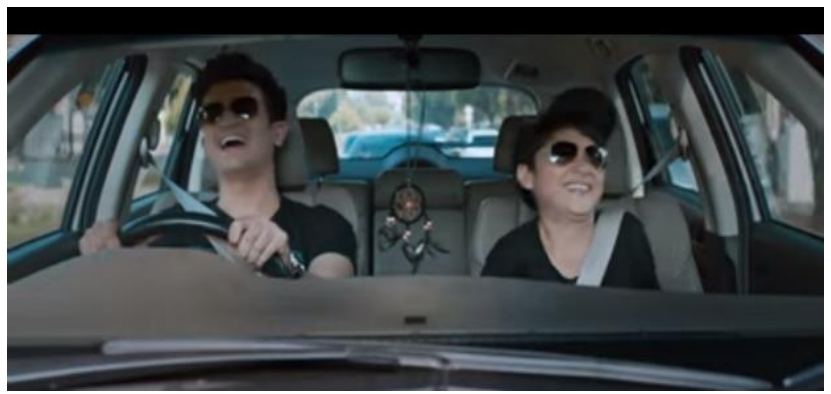

Fig. 2. Gagah drive a car with her sister, and with the appearance of a young man who has a luxurious life and likes having fun.

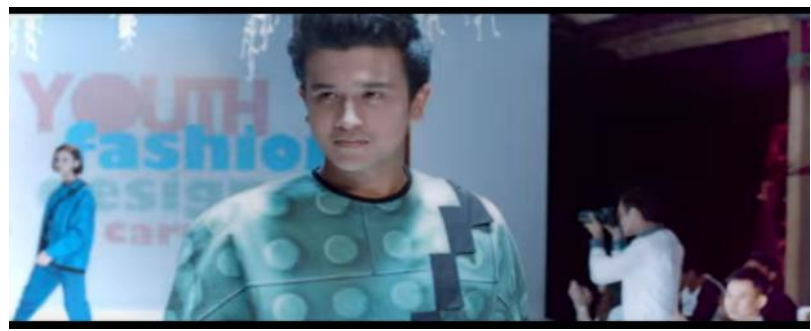

Fig. 3. Gagah is as a cover magazine and fashion model

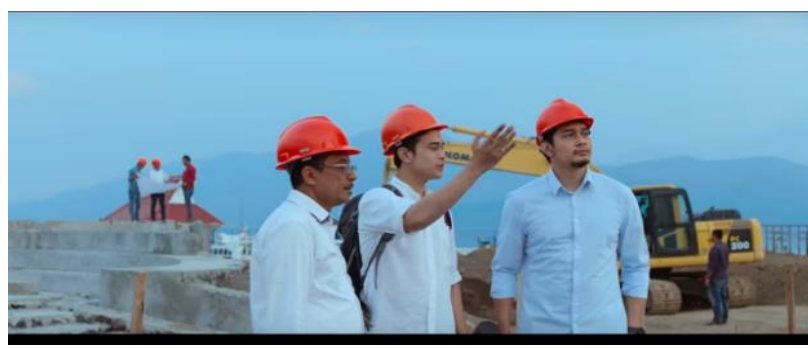

Fig. 4. Gagah is student in the faculty of architectural engineering 


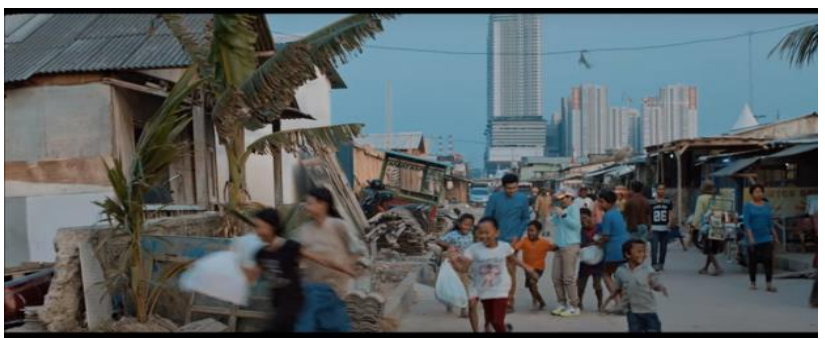

Fig. 5. Gagah prefer to share with poor children

\section{CONCLUSION}

The abundance of Islamic novel books today has an impact on the flourishing of the films that proclaim Islamic syiar. This is to prove that people in Indonesia, especially Muslims are very appreciative of Islamic literature that can master the world of Indonesian film that was conventional and did not lift the values of education and goodness. So through Islamic films cinema can be one of the most effective Islamic poetry. This phenomenon can be interpreted that religion has been in direct contact with popular culture that is fully supported by the power of communication media. That way, the film can be seen as a representation of Muslims to urge Islamic values in society. The film as a medium of da'wah is expected to portray itself well in relation to convey da'wah, with the film can be used as a medium of information in other words inform positive things about Islamic values include some material; aqidah, worship and morals; can provide education.

Many Islamic films produced recently have been an attempt to showcase Islam and the true identity of Muslims.

Duka Sedalam Cinta Movie analyzed by John Fiske's Semiotics theory contains Islamic values that can show the Muslim identity that is known in our environment through the codes contained on the three levels of John Fiske's television that is the costumes, dialogue, and class of the movie performers. In addition, Islamic values are also represented as good behavior (akhlak) individually, to others and also to Allah Subhanahu Wata'ala. Islamic values are represented as servants or ta'at in worshiping their Lord, the Lord of the Universe. Islamic values at the level of belief are represented as something directly related to God, the Almighty.

Behind Islamic films on the screen of Indonesian cinema, there is one thing we should know that almost all the Islamic films are familiar in the community of Islamic film lovers derived or lifted from the works - fiction writers of Islam in Indonesia. The emergence of Islamic films is inseparable from the masterpieces of young Indonesian writers of fiction (the writers) who want to present Islamic values in every story they write.

\section{REFERENCES}

[1] Syah, Hakim. "Dakwah Dalam Film Islam Di Indonesia (Antara Idealisme Dakwah Dan Komodifikasi Agama)", Jurnal dakwah, vol. xiv, no. 2, 2013.

[2] Ruben, Brent D dan Lea P. Stewart. "Komunikasi dan Perilaku Manusia”. Jakarta: Rajawali Pers. 2013.

[3] Piliang, Yasraf Amir. "Hipersemiotika; Tafsir Cultural Studies Atas Matinya Makna”. Yogyakarta; Jalasutra, 2003

[4] Ardianto, Elvinaro dan Lukiati Komala Erdinaya, "Komunikasi Massa Suatu Pengantar”. Bandung: Simbiosa Rekatama Media. 2005.

[5] Fiske, John. "Cultural and Communication Studies: Sebuah Pengantar Paling Komprehensif”. Yogyakarta: Jala Sutra. 2007.

[6] Kusnawan, Aep dkk. "Komunikasi dan Penyiaran Islam". Bandung: Benang Merah Press. 2004.

[7] Muhtadi, Ali. "Penanaman Nilai-Nilai Agama Islam Dalam Pembentukan Sikap Dan Perilaku Siswa Sekolah Dasar Islam Terpadu Luqman Al-Hakim Yogyakarta”. Jurnal Penelitian dan Evaluasi Pendidikan No.1 tahun VIII. 2006.

[8] Moleong, J., Lexy "Metodologi Penelitian Kualitatif”. Bandung: Remaja Rosdakarya. 2017.

[9] Poerwandari, Kristi. "Pendekatan Kualitatif dalam Penelitian Perilaku Manusia”. Depok: LPSP3 FP UI. 2005. 